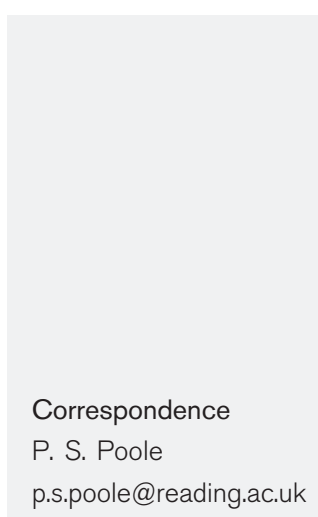

Received 29 June 2005

Accepted 11 July 2005

\section{A family of promoter probe vectors incorporating autofluorescent and chromogenic reporter proteins for studying gene expression in Gram-negative bacteria}

\author{
R. Karunakaran, T. H. Mauchline, A. H. F. Hosiet and P. S. Poole \\ School of Biological Sciences, University of Reading, Whiteknights, PO Box 228, Reading \\ RG6 6AJ, UK
}

\begin{abstract}
A series of promoter probe vectors for use in Gram-negative bacteria has been made in two broad-host-range vectors, pOT ( $\mathrm{pBBR}$ replicon) and pJP2 (incP replicon). Reporter fusions can be made to gfpUV, gfpmut3.1, unstable gfpmut3.1 variants (LAA, LVA, AAV and ASV), gfp+, dsRed2, dsRedT.3, dsRedT.4, mRFP1, gusA or lacZ. The two vector families, pOT and pJP2, are compatible with one another and share the same polylinker for facile interchange of promoter regions. Vectors based on pJP2 have the advantage of being ultra-stable in the environment due to the presence of the parABCDE genes. As a confirmation of their usefulness, the dicarboxylic acid transport system promoter $\left(d c t A_{p}\right)$ was cloned into a pOT (pRU1097)- and a pJP2 (pRU1156)-based vector and shown to be expressed by Rhizobium leguminosarum in infection threads of vetch. This indicates the presence of dicarboxylates at the earliest stages of nodule formation.
\end{abstract}

\section{INTRODUCTION}

The fusing of promoters of interest to a reporter gene has greatly enhanced our ability to study gene expression both in the laboratory and in natural environments. Various reporter gene systems, including lacZ (Labes et al., 1990), gusA (Prell et al., 2002; Reeve et al., 1999), luc and lux (Prosser et al., 1996) and inaZ (Miller et al., 2000) have all been used for molecular genetic analyses. More recently, autofluorescent proteins (AFPs) have been used widely (Gage, 2002; Stuurman et al., 2000; Xi et al., 2001). The most common of these is green fluorescent protein (GFP), a monomeric $23 \mathrm{kDa}$ protein, which was isolated from luminous coelenterates of the genus Aequorea (Chalfie et al., 1994). GFP contains a natural chromophore in an internal hexapeptide, which requires $\mathrm{O}_{2}$ for cyclization (Chalfie et al., 1994; Inouye \& Tsuji, 1994). The threedimensional structure of GFP has been solved, and this shows that it has 11 antiparallel beta strands forming a cylinder (or beta-can) that surrounds an inner alpha-helix where the chromophore is located (Yang et al., 1996). This structure functions to protect the chromophore and confers the stability of the native GFP protein. The great advantage

†Present address: Department of Microbiology, The Dental Institute, King's College London, Floor 28, Guy's Tower, Guy's Hospital, London SE1 9RT, UK.

Abbreviations: AFP, autofluorescent protein; FAC sorter, fluorescenceactivated cell sorter; FACS, fluorescence-activated cell sorting; GFP, green fluorescent protein. of GFP as a reporter protein is that its autofluorescence does not require any cofactors for expression, enabling its detection at the single-cell level via non-destructive sampling. It can also be viewed under a wide range of conditions, such as in agar plates, fluorescent plate readers as well as by fluorescence-activated cell sorting (FACS).

In addition to the wild-type protein, there are many derivatives of GFP, which have increased levels of fluorescence emission, and shifted excitation or emission spectra (Cormack et al., 1996; Crameri et al., 1996; Ellenberg et al., 1998). GFPUV has mutations at F99S, M153T and V163A, produced by shuffle mutagenesis, which result in a 16-fold higher emission than wild-type GFP, but it retains the wildtype excitation spectrum (Crameri et al., 1996). GFPUV appears to have a higher fluorescence emission because it is more soluble than wild-type GFP. Site-directed mutagenesis of wild-type $g f p$ has been used to change F64L and S65T to produce a series of GFPmut derivatives that have a redshifted excitation spectrum (excitation maximum $488 \mathrm{~nm}$ ) and a 35-fold increase in fluorescence, giving them characteristics close to those of FITC, and therefore making them better suited to FAC sorters (Cormack et al., 1996). Furthermore, the addition of a protease-targeting signal to GFPmut has led to the creation of a suite of GFPmut proteins with different stabilities (Anderson et al., 1998). A further derivative, GFP +, has been produced that incorporates the chromophore change from GFPmut3.1 into the protein backbone of GFPUV, giving up to a 130 -fold 
increase in fluorescence emission (Scholz et al., 2000). This is due to the combination of the red-shifted chromophore of GFPmut3.1 with the greater solubility of GFPUV. GFP mutants with blue, cyan and yellowish-green emission spectra are now available, but none of these mutants has emission spectra at wavelengths longer than $529 \mathrm{~nm}$, and as such are limited for dual-labelling experiments with GFP (Baird et al., 2000). However, another fluorescent protein, DsRed, which is $28 \mathrm{kDa}$ in size and originally isolated from corals of the genus Discoma (Baird et al., 2000), shares certain structural and chromophore motifs with GFP, but has an emission maximum of $583 \mathrm{~nm}$, and so can be used in conjunction with GFP. A disadvantage of wild-type DsRed is that it is tetrameric and is slow to mature compared to GFP. However, mutant derivatives, DsRedT.3 and DsRedT.4, have recently been isolated, which, while still yielding tetrameric proteins, mature much faster than the wild-type (Bevis \& Glick, 2002). In addition, a more rapidly maturing monomeric variant of DsRed has been developed, called monomeric red fluorescent protein (mRFP1) (Campbell et al., 2002).

Due to the advantages of AFPs as reporter proteins, a large number of vectors incorporating them have been made (Allaway et al., 2001; Miller et al., 2000; Stuurman et al., 2000). However, we considered it would be of great use if a suite of these AFPs was available in the same polylinker background in two compatible vectors, enabling the easy switching of promoters between vectors. In many cases it is still desirable to use chromogenic reporter systems (GusA and LacZ), which have increased sensitivity relative to AFPs and have been the 'gold standard' for decades. We therefore developed two families of stable vectors, containing a compatible polylinker upstream of various $g f p$ derivatives, gusA, lacZ, dsRed derivatives and $m R F P 1$, suitable for use in Gram-negative bacteria in the environment.

\section{METHODS}

Bacterial strains and growth conditions. The bacterial strains and plasmids used in this study are listed in Table 1. Escherichia coli strains were grown at $37^{\circ} \mathrm{C}$ in Luria-Bertani broth (LB) or agar (LA). Rhizobium leguminosarum 3841 was grown at $28^{\circ} \mathrm{C}$ on either tryptone-yeast extract (TY) (Beringer, 1974), acid minimal salts (AMS), or acid minimal salts agar (AMA) (Poole et al., 1994a) with $10 \mathrm{mM}$ D-glucose or succinate and $10 \mathrm{mM}$ ammonium chloride as sole sources of carbon and nitrogen, respectively. Antibiotics were used at the following concentrations: streptomycin, $500 \mu \mathrm{g} \mathrm{ml}^{-1}$; chloramphenicol, $10 \mu \mathrm{g} \mathrm{ml}^{-1}$; kanamycin $40 \mu \mathrm{g} \mathrm{ml}^{-1}$; tetracycline, $2 \mu \mathrm{g} \mathrm{ml}^{-1}$ (in AMS), $5 \mu \mathrm{g} \mathrm{ml}^{-1}$ (in TY), $10 \mu \mathrm{g} \mathrm{ml}^{-1}$ (in LA); gentamicin, $20 \mu \mathrm{g} \mathrm{ml}^{-1}$ (for E. coli $10 \mu \mathrm{g} \mathrm{ml}^{-1}$ ).

Genetics and molecular biology. All general DNA cloning and analysis was performed as previously described (Sambrook \& Russell, 2001). gfpmut3.1 and its unstable derivatives (LAA, LVA, AAV and ASV), gfp+, gusA, lacZ, dsRed2.0 (Clontech), dsRed T.3 and $T .4$ and the monomeric red fluorescent protein $m R F P 1$ were PCR-amplified from different vectors (see Table 1 for details), using the oligonucleotide primers listed in Table 2. The primers included SpeI and SacI sites at the $5^{\prime}$ ends to allow cloning, except for the primers for lacZ (p348 and p349), which contained SpeI and XhoI sites.
PCR reactions were conducted in $100 \mu \mathrm{l}$, using $2 \cdot 5$ units Pfu Turbo (Stratagene), 10-30 ng genomic DNA, $1 \times$ PCR buffer (Stratagene), $0 \cdot 2 \mathrm{mM}$ dNTPs, $1 \mu \mathrm{M}$ primers. The cycling conditions were as follows: 1 cycle of $95^{\circ} \mathrm{C}$ for $2 \mathrm{~min}, 30$ cycles of $95^{\circ} \mathrm{C}$ for $45 \mathrm{~s}, 57^{\circ} \mathrm{C}$ for $45 \mathrm{~s}, 72^{\circ} \mathrm{C}$ for $2 \mathrm{~min}$ and a final extension of $72^{\circ} \mathrm{C}$ for $10 \mathrm{~min}$. All these PCR products were then cloned into pCR2.1 (Invitrogen) according to the manufacturer's protocol. Once the PCR products were cloned, the plasmids were digested with relevant restriction enzymes and subsequently ligated into pOT2 (a pBBR replicon). Reporter fusions were then transferred from pOT2 to pJP2 (derived from pTR101, an incP replicon), carrying across the entire polylinker. The cloning of $g f p+$ was slightly different in that the SpeI-XhoI fragment of $g f p+$, rather than the SpeI-SacI fragment that was used for other $g f p$ genes, was used to replace the SpeI-XhoI fragment in the $g f p U V$ gene of pOT2. This leaves the $g f p U V$ backbone intact but replaces the F64L and S65T mutations in the chromophore. This was done because the $g f p U V$ of pOT2 has had the Sall site removed by site-directed mutagenesis (Allaway et al., 2001). Brief details of the cloning of $g f p+$ have already been described in a parallel study (Hosie et al., 2002), but are included here in greater detail.

All DNA inserts were confirmed by sequencing (MWG Germany). All plasmids were conjugated into rhizobial strains, using pRK2013 as a helper plasmid to provide the transfer genes, as previously described (Poole et al., 1994b).

Measurement of reporter fusion activity. GFP fluorescence was measured using a Tecan GENios fluorometer equipped with excitation filters of $390 \mathrm{~nm}$ (for GFPUV) and $485 \mathrm{~nm}$ (for GFPmut3.1 and all other GFP derivatives), and emission filter $510 \mathrm{~nm}$. Strain 3841 , containing various pOT2 derivatives with the $d c t A$ promoter cloned into them, was grown in AMS supplemented with $10 \mathrm{mM}$ succinate or glucose. When the cells reached an $\mathrm{OD}_{595}$ of $0 \cdot 4-0 \cdot 6$, the specific fluorescence was measured by dividing the fluorescence of the sample by the OD.

For measurement of $\beta$-D-glucuronidase (GusA) activity on agar plates, AMA was supplemented with 5-bromo-4-chloro-3-indolyl $\beta$-Dglucuronic acid (X-Glc) to a final concentration of $40 \mu \mathrm{g} \mathrm{ml}^{-1}$ and for LacZ, 5-bromo-4-chloro-3-indolyl $\beta$-D-galactopyranoside (X-Gal) was added at a final concentration of $40 \mu \mathrm{g} \mathrm{ml}^{-1}$. In liquid culture, $\beta$-glucuronidase activity was measured as previously described for $\beta$-galactosidase reactions (Lodwig et al., 2004), except that $p$-nitrophenyl- $\beta$-D-glucuronide was substituted as the chromogenic substrate.

Microscopy. Microscopy was performed with a Carl Zeiss Axioskop2.0 epifluorescence microscope with appropriate fluorescence sets. Images were captured using an Axiocam digital camera. For GFPmut3.1 and DsRed the FITC filter set (no. 10, 450-470 nm excitation band pass), and the rhodamine filter set (no. 15, 450-490 nm excitation band pass), respectively, were used.

Plant growth and inoculation. Vetch (Vicia sativa) seeds were surface-sterilized in $95 \%$ ethanol for $30 \mathrm{~s}$ and then immersed in a solution of $2 \%$ sodium hypochlorite for $10 \mathrm{~min}$. The seeds were washed extensively with sterile water and then allowed to germinate on Falcon tube slopes made from $0.75 \%$ agarose containing nitrogen-free rooting solution (Poole et al., 1994a) for 3 days in the dark. The plants were then inoculated with $10^{3}-10^{5}$ c.f.u. bacteria. The tubes were then placed in a growth chamber $\left(23^{\circ} \mathrm{C}, 16 \mathrm{~h} / 8 \mathrm{~h}\right.$ light/dark period). Three to seven days post-inoculation, the plants were examined for the formation of infection threads.

\section{RESULTS AND DISCUSSION}

In this work we have made a family of vectors which contain either gfpmut3.1, the unstable derivatives of gfpmut3.1, 
Table 1. Bacterial strains and plasmids used in this study

Ap, ampicillin; Gm, gentamicin; Tc, tetracycline.

\begin{tabular}{|c|c|c|}
\hline Strain or plasmid & Description & Source/reference \\
\hline \multicolumn{3}{|l|}{ E. coli } \\
\hline E. coli $\mathrm{TOP} 10$ & 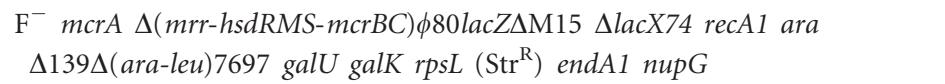 & Invitrogen \\
\hline E. coli $\mathrm{DH} 5 \alpha \mathrm{T}-1$ & $\begin{array}{l}\mathrm{F}^{-} \phi 80 \text { lacZAM15 } \Delta(\text { lacZYA-argF }) \mathrm{U} 169 \operatorname{recA1} \text { endA1 } h s d R 17\left(\mathrm{r}_{\mathrm{k}}^{-}, \mathrm{m}_{\mathrm{k}}^{+}\right) \\
\text {phoA supE44 thi-1 gyrA96 relA1 tonA }\end{array}$ & Invitrogen \\
\hline \multicolumn{3}{|l|}{ R. leguminosarum } \\
\hline 3841 & Str derivative of $R$. leguminosarum biovar viciae strain 300 & Johnston \& Beringer (1975) \\
\hline RU1416 & 3841 containing $\mathrm{pJP} 2$ & This work \\
\hline RU1683-RU1692 & 3841 with plasmids pRU1119-pRU1128 containing $\operatorname{dct} A_{\mathrm{p}}$ & This work \\
\hline RU1708 & 3841 containing pRU1140 & This work \\
\hline RU1709 & 3841 containing pRU1141 & This work \\
\hline RU1712 & 3841 containing pRU1147 & This work \\
\hline RU1713 & 3841 containing pRU1148 & This work \\
\hline RU1715 & 3841 containing pRU1156 & This work \\
\hline RU1716 & 3841 containing pRU1157 & This work \\
\hline RU1724 & 3841 containing pRU1164 & This work \\
\hline RU1725 & 3841 containing pRU1161 & This work \\
\hline RU1728 & 3841 containing pRU1167 & This work \\
\hline \multicolumn{3}{|l|}{ Plasmids } \\
\hline pCR2.1TOPO & $\mathrm{Ap}^{\mathrm{r}}, \mathrm{Km}^{\mathrm{r}}$; PCR product cloning vector & Invitrogen \\
\hline pOT2 & $\mathrm{Gm}^{\mathrm{r}}$; promoter probe vector with promoterless $g f p U V$ & Allaway et al. (2001) \\
\hline pJP2 & $\mathrm{Tc}^{\mathrm{r}}$; stable broad-host-range cloning vector & Prell et al. (2002) \\
\hline pBJA27 & $\mathrm{Ap}^{\mathrm{r}} ;$ gfpmut3.1 & Anderson et al. (1998) \\
\hline pBJA110 & $\mathrm{Ap}^{\mathrm{r}} ; g f p m u t 3.1$ (LAA) & \\
\hline pBJA111 & Ap $;$ gfpmut3.1 (LVA) & \\
\hline pBJA112 & $\mathrm{Ap}^{\mathrm{r}} ;$ gfpmut3.1 (AAV) & \\
\hline pBJA113 & Ap ${ }^{\mathrm{r}} ; g f p m u t 3.1$ (ASV) & \\
\hline DsRed2.0 & $\mathrm{Ap}^{\mathrm{r}} ;$ dsRed2.0 from Discosoma & Clontech \\
\hline DsRedT.3, DsRedT.4 & $A p^{r}$; fast-maturing versions of $d s R e d 2.0$ & Bevis \& Glick (2002) \\
\hline mRFP1 & $\mathrm{Ap}^{\mathrm{r}} ;$ mRFP1 from Discosoma in $\mathrm{pRSET}_{\mathrm{B}}$ & Campbell et al. (2002) \\
\hline pMN402 & Hygromycin ${ }^{\mathrm{r}} ; g f p+$ & Scholz et al. (2000) \\
\hline pMP220 & $\begin{array}{l}\mathrm{Tc}^{\mathrm{r}} \text {; IncP broad-host-range mobilizable promoter probe vector employing } \\
\text { E. coli lac } Z \text { as reporter gene }\end{array}$ & Spaink et al. (1987) \\
\hline pRK2013 & $\begin{array}{l}\mathrm{Km}^{\mathrm{r}} \text {; ColEI replicon with RK2 tra genes, helper plasmid used for } \\
\text { mobilizing plasmids }\end{array}$ & Figurski \& Helinski (1979) \\
\hline $\operatorname{pRSET}_{\mathrm{B}}$ & $\mathrm{Ap}^{\mathrm{r}}$; T7 expression vector & Invitrogen \\
\hline pRU491 & $\begin{array}{l}\mathrm{Gm}^{\mathrm{r}} \text {; SpeI-HindIII fragment containing the } d p p \text { promoter from } R \text {. } \\
\text { leguminosarum strain } 3841\end{array}$ & This work \\
\hline pRU604 & $\mathrm{Gm}^{\mathrm{r}}$; PmeI-HindIII fragment containing the xylose kinase promoter & This work \\
\hline pRU977 & pRU1701 containing the $\operatorname{dct} A$ promoter & This work \\
\hline pRU1064 & $\mathrm{Tc}^{\mathrm{r}}$; HindIII-SacI fragment containing $g f p U V$ from pOT2 cloned into pJP2 & This work \\
\hline pRU1097 & $\begin{array}{l}\mathrm{Gm}^{\mathrm{r}} ; \mathrm{p} 318 / \mathrm{p} 319 \text { PCR product (gfpmut3.1) from pBJA27 cloned in pOT2 } \\
\text { as SpeI-SacI }\end{array}$ & This work \\
\hline pRU1098 & $\begin{array}{l}\mathrm{Gm}^{\mathrm{r}} ; \mathrm{p} 318 / \mathrm{p} 320 \text { PCR product; (gfpmut3.1 LAA) from pBJA110 cloned in } \\
\text { pOT2 as SpeI-SacI }\end{array}$ & This work \\
\hline pRU1099 & $\begin{array}{l}\mathrm{Gm}^{\mathrm{r}} ; \mathrm{p} 318 / \mathrm{p} 321 \mathrm{PCR} \text { product }(g f p m u t 3.1 \mathrm{LVA}) \text { from pBJA111 cloned in } \\
\text { pOT2 as SpeI-SacI }\end{array}$ & This work \\
\hline pRU1100 & $\begin{array}{l}\mathrm{Gm}^{\mathrm{r}} ; \mathrm{p} 318 / \mathrm{p} 322 \mathrm{PCR} \text { product }(g f p m u t 3.1 \mathrm{AAV}) \text { from } \mathrm{pBJA} 112 \text { cloned in } \\
\text { pOT2 as SpeI-SacI }\end{array}$ & This work \\
\hline pRU1101 & $\begin{array}{l}\mathrm{Gm}^{\mathrm{r}} ; \mathrm{p} 318 / \mathrm{p} 323 \text { PCR product (gfpmut3.1 ASV) from pBJA113 cloned in } \\
\text { pOT2 as SpeI-SacI }\end{array}$ & This work \\
\hline pRU1102 & $\begin{array}{l}\mathrm{Gm}^{\mathrm{r}} ; \mathrm{p} 201 / \mathrm{p} 203 \text { PCR product }(g u s A) \text { from pJP2 cloned in pOT2 as } \\
\text { SpeI-SacI }\end{array}$ & This work \\
\hline
\end{tabular}


Table 1. cont.

\begin{tabular}{|c|c|c|}
\hline Strain or plasmid & Description & Source/reference \\
\hline pRU1103 & $\begin{array}{l}\mathrm{Gm}^{\mathrm{r}} ; \mathrm{p} 348 / \mathrm{p} 349 \text { PCR product (lacZ) from pMP220 cloned in pOT2 as } \\
\text { SpeI-XhoI }\end{array}$ & This work \\
\hline pRU1104 & $\begin{array}{l}\mathrm{Gm}^{\mathrm{r}} ; \mathrm{p} 346 / \mathrm{p} 347 \text { PCR product (DsRed2.0) from DsRed2.0 cloned in pOT2 } \\
\text { as SpeI-SacI }\end{array}$ & This work \\
\hline pRU1105 & $\begin{array}{l}\mathrm{Gm}^{\mathrm{r}} ; \mathrm{p} 385 / \mathrm{p} 386 \text { PCR product (DsRedT.3) from DsRedT.3 cloned in pOT2 } \\
\text { as SpeI-SacI }\end{array}$ & This work \\
\hline pRU1106 & $\begin{array}{l}\mathrm{Gm}^{\mathrm{r}} ; \mathrm{p} 385 / \mathrm{p} 386 \text { PCR product (DsRedT.4) from DsRedT.4 cloned in pOT2 } \\
\text { as SpeI-SacI }\end{array}$ & This work \\
\hline pRU1119-pRU1128 & $\begin{array}{l}\mathrm{Gm}^{\mathrm{r}} \text {; } d c t A \text { promoter from pRU977 cloned in pRU1097-pRU1106, respectively, } \\
\text { using SphI-SstII sites }\end{array}$ & This work \\
\hline pRU1140 & $\mathrm{Gm}^{\mathrm{r}}$; $d p p$ promoter from pRU491 cloned in pRU1104 as SpeI-HindIII sites & This work \\
\hline pRU1141 & $\mathrm{Gm}^{\mathrm{r}}$; $d p p$ promoter from pRU491 cloned in pRU1105 as SpeI-HindIII sites & This work \\
\hline pRU1144 & $\begin{array}{l}\mathrm{Gm}^{\mathrm{r}} ; \mathrm{p} 408 / \mathrm{p} 409 \text { PCR product }(m R F P 1) \text { from } \mathrm{pRSET}_{\mathrm{B}} \text { cloned in pOT2 as } \\
\text { SpeI-SacI }\end{array}$ & This work \\
\hline pRU1147 & $\begin{array}{l}\mathrm{Tc}^{\mathrm{r}} \text {; xylose promoter from pRU604 cloned in pRU1144 using PmeI-HindIII } \\
\text { sites }\end{array}$ & This work \\
\hline pRU1148 & $\mathrm{Gm}^{\mathrm{r}}$; $d p p$ promoter from pRU491 cloned in pRU1144 as SpeI-HindIII sites & This work \\
\hline pRU1156 & $\begin{array}{l}\mathrm{Tc}^{\mathrm{r}} \text {; HindIII-SacI fragment containing gfpmut3.1 from pRU1097 cloned into } \\
\text { pJP2 }\end{array}$ & This work \\
\hline pRU1157 & $\begin{array}{l}\mathrm{Tc}^{\mathrm{r}} \text {; xylose promoter from pRU604 cloned in pRU1156 using PmeI-HindIII } \\
\text { sites }\end{array}$ & This work \\
\hline pRU1161 & $\mathrm{Tc}^{\mathrm{r}}$; HindIII/SacI fragment containing $m R F P 1$ from pRU1144 cloned into pJP2 & This work \\
\hline pRU1164 & $\mathrm{Tc}^{\mathrm{r}}$; $d p p$ promoter from pRU491 cloned in pRU1161 as SpeI-HindIII sites & This work \\
\hline pRU1167 & $\begin{array}{l}\mathrm{Tc}^{\mathrm{r}} \text {; xylose promoter from pRU604 cloned in pRU1064 using PmeI-HindIII } \\
\text { sites }\end{array}$ & This work \\
\hline pRU1701 & $\mathrm{Gm}^{\mathrm{r}}$; promoter probe vector with promoterless $g f p+$ & Hosie et al. (2002) \\
\hline pRU1716 & $\mathrm{Gm}^{\mathrm{r}}$; SphI-SstII fragment containing $d c t A$ promoter in pOT2 & Poole et al. (1994b) \\
\hline
\end{tabular}

Table 2. Primers used in the study

For all unstable GFP derivatives, p318 was used as the forward primer in conjunction with the respective reverse primers. SacI and SpeI restriction sites are in bold type.

\begin{tabular}{|c|c|c|}
\hline Primer & Sequence & Gene \\
\hline P201 & GAGAGAGAACTAGTGGAGGAAGAAAAAATGTTACGTCCTGTAGAAAC & gusA forward \\
\hline P203 & GAGAGAGAGAGCTCTCATTGTTTGCCTCCCTGCT & gus A reverse \\
\hline p319 & CTCTCGAGCTCATTTGTATAGTTCATCCATGC & mut3.1 reverse \\
\hline p320 & CTCTCGAGCTCATTAAGCTGCTAAAGCGTAG & mut3.1LAA reverse \\
\hline p323 & CTCTCGAGCTCATTAAACTGATGCAGCGTAG & mut3.1ASV reverse \\
\hline p346 & GAGAACTAGTGGAGGAAGAAAAAATGGCCTCCTCCGAGAACGTCATC & DsRed2.0 forward \\
\hline p347 & CTGAGCTCCTACAGGAACAGGTGGTGGCGG & DsRed2.0 reverse \\
\hline p348 & CCACTAGTGGAGGAAGAAAAAATGACCATGATTACGGATTC & lacZ forward \\
\hline p349 & GAGACTCGAGTTATTTTTGACACCAGACCA & lac $Z$ reverse \\
\hline
\end{tabular}


Table 3. Summary of reporter fusions

\begin{tabular}{|c|c|c|c|c|c|c|c|c|}
\hline Plasmid & Replicon & $\begin{array}{l}\text { Size } \\
(\mathbf{k b})\end{array}$ & $\begin{array}{c}\text { Accession } \\
\text { number }\end{array}$ & Resistance & Reporter & $\begin{array}{l}\text { Excitation } \\
\text { maximum } \\
\quad(\mathrm{nm})\end{array}$ & $\begin{array}{l}\text { Emission } \\
\text { maximum } \\
\quad(\mathbf{n m})\end{array}$ & Detection/uses ${ }^{\star}$ \\
\hline pRU1701 & pBBR & $5 \cdot 3$ & AJ851277 & Gentamicin & GFP + & $\begin{array}{c}491 \\
\text { (Shoulder at 396) }\end{array}$ & 512 & Plates/microscopy \\
\hline pRU1099 & $\mathrm{pBBR}$ & $5 \cdot 3$ & AJ851280 & Gentamicin & Unstable GFPmut3.1 AAV & 488 & 509 & Microscopy \\
\hline pRU1100 & $\mathrm{pBBR}$ & $5 \cdot 3$ & AJ851281 & Gentamicin & Unstable GFPmut3.1 LVA & 488 & 509 & Microscopy \\
\hline pRU1101 & pBBR & $5 \cdot 3$ & AJ851282 & Gentamicin & Unstable GFPmut3.1 ASV & 488 & 509 & Microscopy \\
\hline pRU1103 & $\mathrm{pBBR}$ & $7 \cdot 9$ & AJ851283 & Gentamicin & LacZ & & & Plates/sectioning \\
\hline pRU1104 & $\mathrm{pBBR}$ & $5 \cdot 3$ & AJ851284 & Gentamicin & DsRed2.0 & 561 & 586 & Microscopy/dual labelling \\
\hline pRU1156 & IncP & 13 & AJ851292 & Tetracycline & GFPmut3.1-GusA & 488 & 509 & Microscopy/sectioning \\
\hline pRU1161 & IncP & 13 & AJ851291 & Tetracycline & mRFP1-GusA & 584 & 607 & Microscopy/dual labelling \\
\hline
\end{tabular}

*Plates, growth on agar plates with detection using a long-wavelength transilluminator; microscopy, suitable for fluorescence microscopy or FACS; sectioning, chromogenic reporter protein allowing sectioning and histological staining; dual labelling, fluorescent microscopy of a red fluorescent protein in conjunction with GFP.

$g f p+, d s R e d 2, T .3, T .4$ or mRFP1 in two broad-host-range vectors. The first vector is based on pOT (pBBR incompatibility group) and the second, pJP2, is based on the ultrastable pTR101 (incP incompatibility group). They have gentamicin (pOT) or tetracycline (pJP2) resistance markers, so they can be introduced into the same background. The properties of the vectors are summarized in Table 3 and Fig. 1. The sequences of the vectors were deduced from the known sequences of their components and the accession numbers are shown (Table 3).

\section{Construction of pOT-based promoter probe vectors}

The mutant protein GFPmut3.1 is approximately 35 -fold more fluorescent than wild-type GFP when excited at $488 \mathrm{~nm}$, but it is only weakly excited by UV light (Cormack et al., 1996). GFPmut3.1, along with all its unstable derivatives (LAA, AAV, LVA and ASV), was cloned into pOT2 as described in Methods, creating pRU1097, pRU1098, pRU1099, pRU1100 and pRU1101, respectively. To examine the expression of these reporter genes, the dicarboxylate transport system promoter $\left(d c t \mathrm{~A}_{\mathrm{p}}\right)$ of $R$. leguminosarum was cloned (Poole et al., 1994b) as a SphI-SstII fragment (from pRU1716) into all pOT derivatives. $R$. leguminosarum cells containing the plasmids were grown overnight on medium containing succinate to induce the fusions, and then the next day the cells were resuspended in medium containing glucose, to remove the inducer (Fig. 2). The unstable GFP derivatives contain a proteolysis targeting peptide at their C-termini and this experiment confirmed that $R$. leguminosarum behaves the same as the original E. coli strains (Anderson et al., 1998). GFP + is reported to be up to 130 -fold brighter than wild-type GFP, so $g f p+$ was cloned into pOT2, creating pRU1701. The dctA promoter was then cloned into pRU1701, creating pRU977, and $g f p+$ was induced specifically by dicarboxylates (Fig. 2). We have previously constructed a pOT2 vector containing GFPUV (Allaway et al., 2001). It should be noted that GFPUV can be used in a plate reader or FAC sorter with excitation at $485 \mathrm{~nm}$, although it gives much lower fluorescence than when excited at $390 \mathrm{~nm}$.

In order to compare expression of GFPmut3.1, GFPUV and GFP + on agar plates, strains containing plasmids with either the inducible $d c t A_{\mathrm{p}}$ or the constitutive monocarboxylate permease promoter $\left(m c t_{\mathrm{p}}\right)$ (Hosie et al., 2002) were grown on AMA with appropriate carbon sources. The expression of GFPUV (excitation $\lambda_{\max } 395 \mathrm{~nm}$ ) and GFP + (excitation $\lambda_{\max } 491 \mathrm{~nm}$, but with a shoulder around $390 \mathrm{~nm}$ ) was visible under the long UV wavelength, but as expected GFPmut3.1 did not fluoresce detectably under this condition (excitation $\lambda_{\max } 488 \mathrm{~nm}$ ). This is a bonus for the use of GFP +, since it can be used both for routine screening of colonies on a long-wavelength transilluminator after growth on agar plates, and in fluorescent plate readers and FAC sorters with excitation at $485 \mathrm{~nm}$. However, it is possible to check the expression of GFPmut3.1 on agar plates with the use of a visi-blue filter (UVB instruments) and this was confirmed with pRU1119. 
(a)
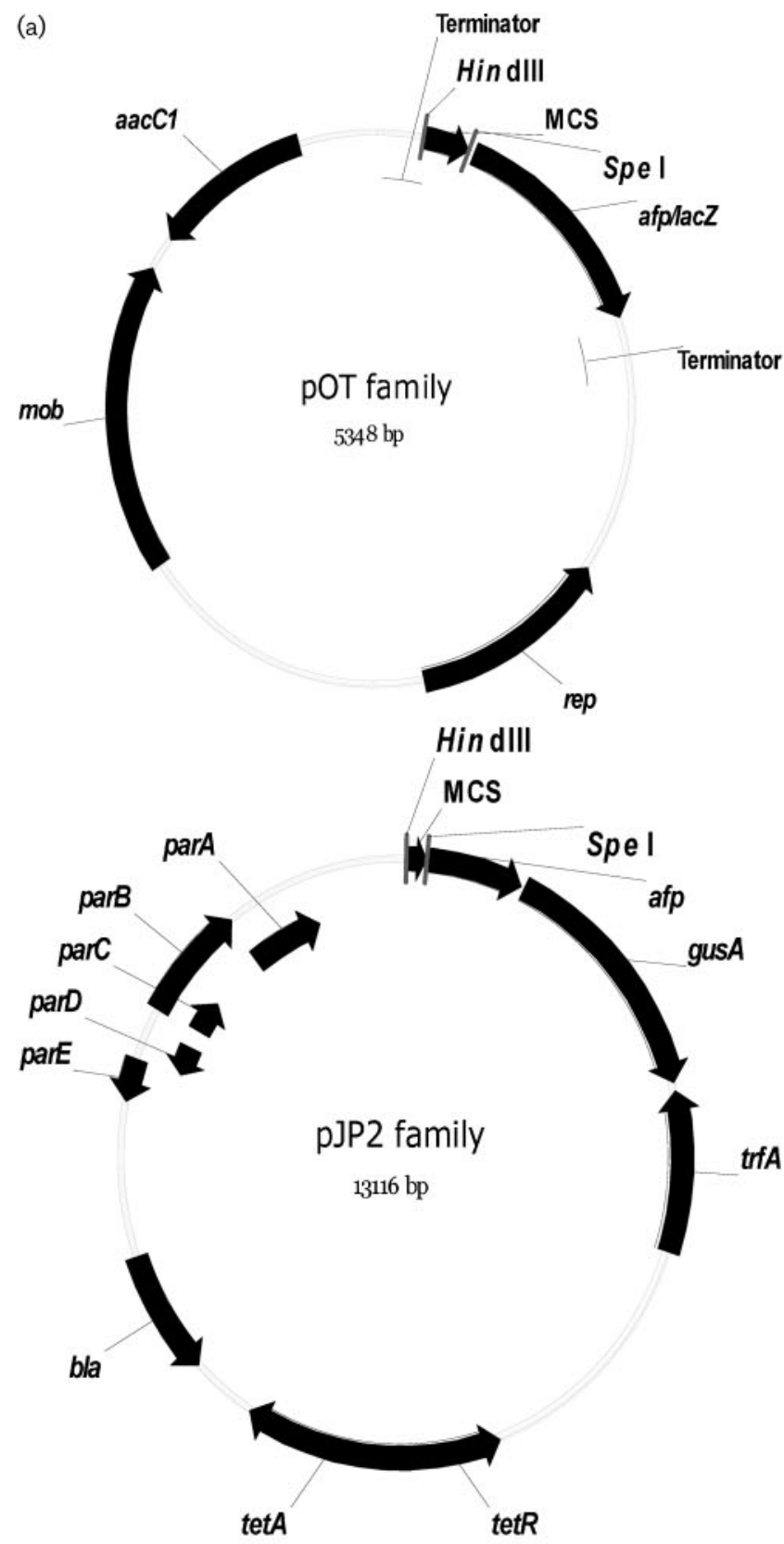

(b)

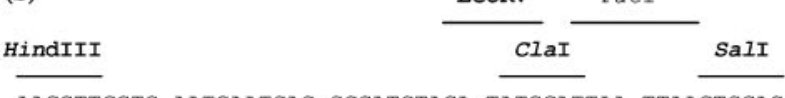

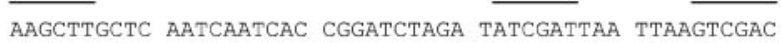

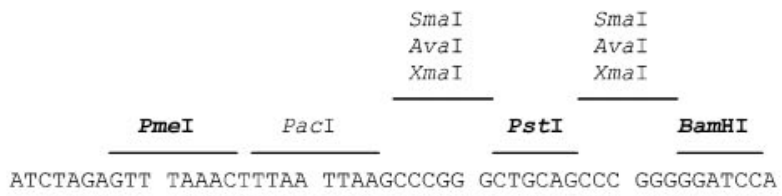

$\frac{\text { HpaI }}{\text { CTAGGTTAAC GCATGCGGGC CCGGTACCAG ATAGAGAGAG AGAGAGACTA GT }} \frac{\text { spnI }}{s \text { tuI }}$

Fig. 1. (a) Maps of pOT- and pJP2-based vectors. (b) Common polylinker of vectors. In (b), unique sites are in bold type.

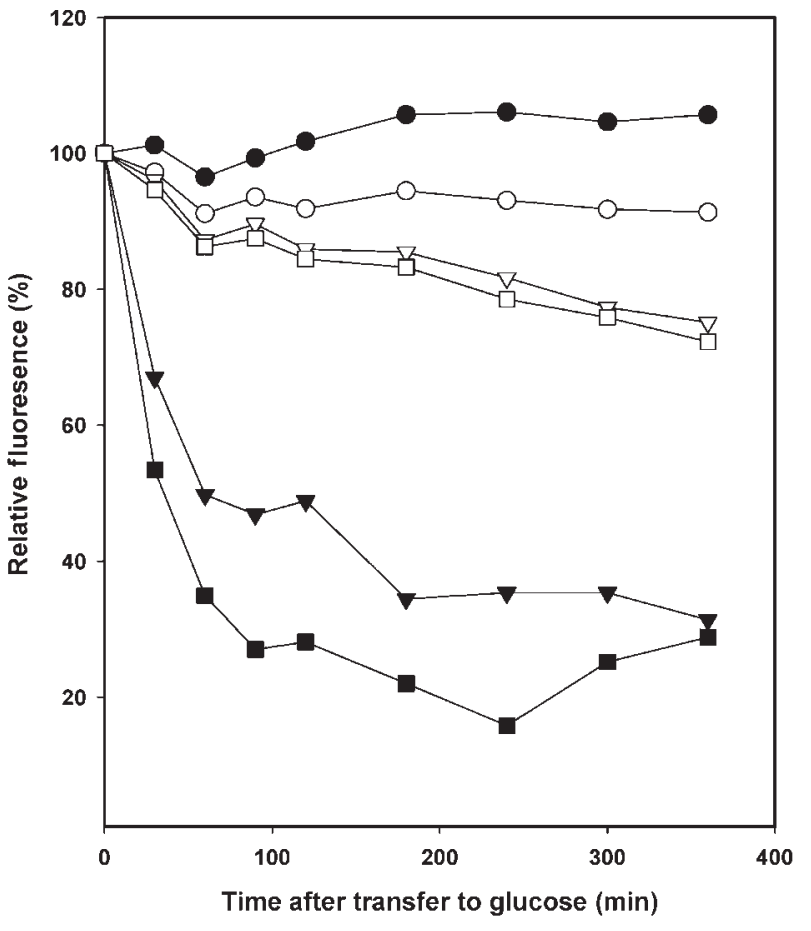

Fig. 2. Stability of Gfp variants in $R$. leguminosarum strain 3841 grown on medium containing succinate then transferred to glucose. All $g f p$ variants are fused to the $\operatorname{dct} A$ promoter. pRU977 (dct $\left.A_{\mathrm{p}}:: g f p+\right) ; \bigcirc, \operatorname{pRU1119}\left[\operatorname{dct} A_{\mathrm{p}}:: g f p(m u t 3.1)\right]$;

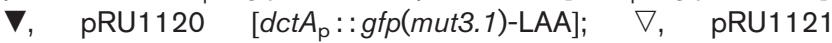
$\left[d c t A_{\mathrm{p}}:: g f p(m u t 3.1)-\mathrm{LVA}\right] ; \mathbf{\square}, \mathrm{pRU} 1122\left[\operatorname{dct} A_{\mathrm{p}}:: g f p(m u t 3.1)-\right.$ $\mathrm{AAV}] ; \square, \mathrm{pRU} 1123\left[\operatorname{dct} A_{\mathrm{p}}:: g f p(m u t 3.1)-\mathrm{ASV}\right]$.

It is often desirable to detect two different AFPs simultaneously. The only other AFP that can be detected at the same time as GFP is DsRed. However, the wild-type DsRed has the disadvantage that it is very slow to mature and is tetrameric. Faster-maturing variants of DsRed have been developed (Bevis \& Glick, 2002) and a new monomeric red fluorescent protein, mRFP1, isolated (Campbell et al., 2002). We therefore cloned DsRed2.0 and its fast-maturing derivatives (T.3 and T.4), as well as $m R F P 1$, into pOT2, creating pRU1104, pRU1105, pRU1106 and pRU1144, respectively.

\section{Construction of ultra-stable IncP-based vectors}

The environmentally stable IncP plasmid, pTR102, was made by addition of the parABCDE genes (Weinstein et al., 1992), and this region was subsequently used to create a stable gusA reporter probe vector (pJP2) (Prell et al., 2002). These vectors are very stable upon repeated subculturing and are completely retained in individual bacteroids in legume nodules, as revealed by histological staining (Prell et al., 2002; Weinstein et al., 1992). To construct a vector with tandem gusA and AFP, gfpmut3.1 and its associated multiple cloning site was cloned as a SacI-HindIII fragment into pJP2, creating pRU1156. In order to check the expression of gfpmut3.1, the xylose promoter (xylA from 
pRU604) of R. leguminosarum was cloned as a PmeI-HindIII fragment into pRU1156, creating pRU1157. The plasmid was conjugated into $R$. leguminosarum, which was grown on AMS medium with glucose or xylose as carbon source, and the specific fluorescence of GFPmut3.1 (764 versus 5890 fluorescence units, respectively) and GusA activity [719 versus $1895 \mathrm{nmol} \mathrm{min}{ }^{-1}$ (mg prot) ${ }^{-1}$, respectively] was measured.

To enable monitoring on agar plates, $g f p U V$ from $p O T 2$ was cloned as a HindIII-SacI fragment into pJP2, deleting the two C-terminal amino acids (YK) and forming pRU1064. The xylA promoter was cloned into pRU1064 and this was conjugated into $R$. leguminosarum. After growth on agar plates containing xylose, it was confirmed that expression was inducible and unaffected by the two-amino-acid deletion (data not shown).

To make a DsRed marked vector in the IncP background that is compatible with pOT2, mRFP1 (a monomeric and fast-maturing derivative of DsRed) was cloned into pJP2, creating pRU1161. As a test, the $d p p$ promoter from strain 3841 was cloned into pRU1161 as a SpeI-HindIII fragment to create pRU1164, resulting in strong expression (data not shown).

As a general observation, $R$. leguminosarum strains containing pOT-based plasmids gave higher fluorescence readings than pJP2-based plasmids. This is probably due to plasmid copy number, since RP4-based plasmids such as pJP2 have a modest copy number of around 25 in E. coli (Fang \& Helinski, 1991) and yields of pOT plasmids isolated from E. coli are much higher than those of pJP2. However, this has not been confirmed by measurement of plasmid copy number in $R$. leguminosarum. For environmental work, the pJP2-based plasmids have the advantage of being ultrastable, with no detectable curing even in single bacteroids stained for GusA activity (Prell et al., 2002). R. leguminosarum carrying pOT plasmids retained the plasmid in $48 \%$ of cells (78 colonies from 13 nodules) recovered from 4week-old pea nodules. This result is similar to the value for vetch plants reported previously (Stuurman et al., 2000) and indicates reasonable stability, but clearly pJP2-based vectors are superior for long-term environmental applications.

\section{Monitoring gene expression in situ}

AFPs are very useful to monitor gene expression of single cells in the environment. To infect plants, rhizobia must first attach to root hairs before growing down a plant-derived infection thread. This ultimately leads to bacteroid formation, where bacteria are engulfed by plant cortical cells. In order to test the expression of AFPs in infection threads, plasmids pRU1119 (GFPmut3.1) and pRU1127 (DsRedT.3), which are under the control of $d c t A_{\mathrm{p}}$, were inoculated onto vetch seedlings. $d c t A_{\mathrm{p}}$ was chosen because its expression in bacteroids is essential for nitrogen fixation (Finan et al., 1981), but it is not known whether it is expressed in infection threads. It can be seen that $\operatorname{dct}_{\mathrm{p}}:: \operatorname{DsRedT.3}$

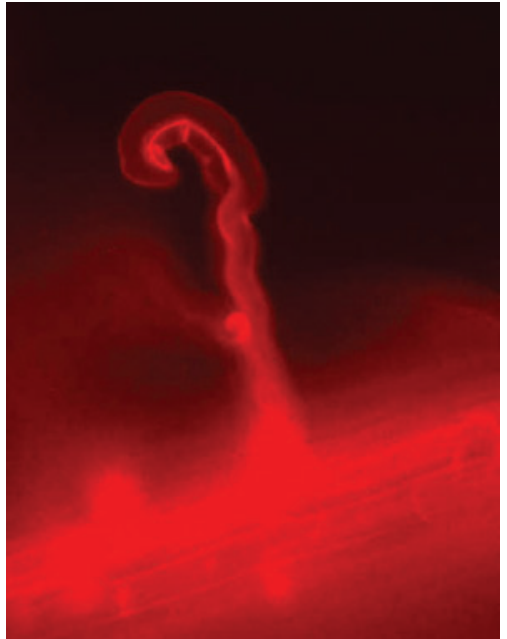

Fig. 3. Root hair of vetch containing a fluorescent infection thread (dsRedT.3) formed by $R$. leguminosarum expressing a $\operatorname{dct} A$ promoter (pRU1127).

was expressed throughout infection threads (Fig. 3), and $\operatorname{dct}_{\mathrm{p}}::$ gfpmut3.1 gave a similar result (data not shown). However, dicarboxylates are not the only carbon sources available during nodule development, since dicarboxylate transport mutants develop into bacteroids (Finan et al., 1981). Thus, while dicarboxylates are available from this early stage of contact between the bacteria and the plant, their absolute requirement for nitrogen fixation by mature bacteroids must be related to the final metabolic cycling with the plant (Lodwig et al., 2003). Other compounds, such as sugars, polyols and amino acids, are likely to be available for growth of $R$. leguminosarum in the infection thread. The vector families developed here are powerful tools with which to investigate this problem.

\section{ACKNOWLEDGEMENTS}

We would like to thank the BBSRC for supporting this research and R. Y. Tsien for providing plasmids.

\section{REFERENCES}

Allaway, D., Schofield, N. A., Leonard, M. E., Gilardoni, L., Finan, T. M. \& Poole, P. S. (2001). Use of differential fluorescence induction and optical trapping to isolate environmentally induced genes. Environ Microbiol 3, 397-406.

Anderson, J. B., Sternberg, C., Poulsen, L. K., Bjorn, S. P., Givskov, M. \& Molin, S. (1998). New unstable variants of green fluorescent protein for studies of transient gene expression in bacteria. Appl Environ Microbiol 64, 2240-2246.

Baird, G. S., Zacharias, D. A. \& Tsien, R. Y. (2000). Biochemistry, mutagenesis, and oligomerization of DsRed, a red fluorescent protein from coral. Proc Natl Acad Sci U S A 97, 11984-11989.

Beringer, J. E. (1974). R factor transfer in Rhizobium leguminosarum. J Gen Microbiol 84, 188-198. 
Bevis, B. J. \& Glick, B. S. (2002). Rapidly maturing variants of the Discosoma red fluorescent protein (DsRed). Nature Biotechnol 20, 83-87.

Campbell, R. E., Tour, O., Palmer, A. E., Steinbach, P., Baird, G. S., Zacharias, D. A. \& Tsien, R. Y. (2002). A monomeric red fluorescent protein. Proc Natl Acad Sci U S A 99, 7877-7882.

Chalfie, M., Tu, Y., Euskirchen, G., Ward, W. W. \& Prasher, D. C. (1994). Green fluorescent protein as a marker for gene expression. Science 263, 802-805.

Cormack, B. P., Valdivia, R. H. \& Falkow, S. (1996). FACS-optimized mutants of the green fluorescent protein (GFP). Gene 173, 33-38.

Crameri, A., Whitehorn, E. A., Tate, E. \& Stemmer, W. P. C. (1996). Improved green fluorescent protein by molecular evolution using DNA shuffling. Nature Biotechnol 14, 315-319.

Ellenberg, J., Lippincott-Schwartz, J. \& Presley, J. F. (1998). Twocolor green fluorescent protein time-lapse imaging. Biotechniques 25, 838-846.

Fang, F. C. \& Helinski, D. R. (1991). Broad-host-range properties of plasmid-RK2 - importance of overlapping genes encoding the plasmid replication initiation protein TrfA. J Bacteriol 173, 5861-5868.

Figurski, D. H. \& Helinski, D. R. (1979). Replication of an origincontaining derivative of plasmid RK2 dependent on a plasmid function provided in trans. Proc Natl Acad Sci U S A 76, 1648-1652.

Finan, T. M., Wood, J. M. \& Jordan, C. (1981). Succinate transport in Rhizobium leguminosarum. J Bacteriol 148, 193-202.

Gage, D. J. (2002). Analysis of infection thread development using Gfp- and DsRed- expressing Sinorhizobium meliloti. J Bacteriol 184, 7042-7046.

Hosie, A. H. F., Allaway, D. \& Poole, P. S. (2002). A monocarboxylate permease of Rhizobium leguminosarum is the first member of a new subfamily of transporters. J Bacteriol 184, 5436-5448.

Inouye, S. \& Tsuji, F. I. (1994). Aequorea green fluorescent protein - expression of the gene and fluorescence characteristics of the recombinant protein. FEBS Lett 341, 277-280.

Johnston, A. W. B. \& Beringer, J. E. (1975). Identification of the Rhizobium strains in pea root nodules using genetic markers. J Gen Microbiol 87, 343-350.

Labes, M., Puhler, A. \& Simon, R. (1990). A new family of RSF1010derived expression and lac-fusion broad-host-range vectors for Gram-negative bacteria. Gene 89, 37-46.

Lodwig, E. M., Hosie, A. H. F., Bourdes, A., Findlay, K., Allaway, D., Karunakaran, R., Downie, J. A. \& Poole, P. S. (2003). Amino-acid cycling drives nitrogen fixation in the legume-Rhizobium symbiosis. Nature 422, 722-726.

Lodwig, E., Kumar, S., Allaway, D., Bourdès, A., Prell, J., Priefer, U. \& Poole, P. (2004). Regulation of L-alanine dehydrogenase in Rhizobium leguminosarum bv. viciae and its role in pea nodules. J Bacteriol 186, 842-849.
Miller, W. G., Leveau, J. H. \& Lindow, S. E. (2000). Improved $g f p$ and inaZ broad-host-range promoter-probe vectors. Mol Plant Microbe Interact 13, 1243-1250.

Poole, P. S., Blyth, A., Reid, C. J. \& Walters, K. (1994a). myo-Inositol catabolism and catabolite regulation in Rhizobium leguminosarum bv viciae. Microbiology 140, 2787-2795.

Poole, P. S., Schofield, N. A., Reid, C. J., Drew, E. M. \& Walshaw, D. L. (1994b). Identification of chromosomal genes located downstream of $d c t D$ that affect the requirement for calcium and the lipopolysaccharide layer of Rhizobium leguminosarum. Microbiology 140, 2797-2809.

Prell, J., Boesten, B., Poole, P. \& Priefer, U. B. (2002). The Rhizobium leguminosarum bv. viciae VF39 gamma aminobutyrate (GABA) aminotransferase gene ( $g a b T)$ is induced by GABA and highly expressed in bacteroids. Microbiology 148, 615-623.

Prosser, J. I., Killham, K., Glover, L. A. \& Rattray, E. A. S. (1996). Luminescence-based systems for detection of bacteria in the environment. Crit Rev Biotechnol 16, 157-183.

Reeve, W. G., Tiwari, R. P., Worsley, P. S., Dilworth, M. J., Glenn, A. R. \& Howieson, J. G. (1999). Constructs for insertional mutagenesis, transcriptional signal localization and gene regulation studies in root nodule and other bacteria. Microbiology 145, 1307-1316.

Sambrook, J. \& Russell, D. W. (2001). Molecular Cloning: a Laboratory Manual, 3rd edn. Cold Spring Harbor, NY: Cold Spring Harbor Laboratory.

Scholz, Q., Thiel, A., Hillen, W. \& Niederweis, M. (2000). Quantitative analysis of gene expression with an improved green fluorescent protein. Eur J Biochem 267, 1565-1570.

Spaink, H. P., Okker, R. J. H., Wijffelman, C. A., Pees, E. \& Lugtenberg, B. J. J. (1987). Promoters in the nodulation region of the Rhizobium leguminosarum SYM plasmid pRL1JI. Plant Mol Biol 9, 27-39.

Stuurman, N., Bras, C. P., Schlaman, H. R. M., Wijfjes, A. H. M., Bloemberg, G. \& Spaink, H. P. (2000). Use of green fluorescent protein color variants expressed on stable broad-host-range vectors to visualize rhizobia interacting with plants. Mol Plant Microbe Interact 13, 1163-1169.

Weinstein, M., Roberts, R. C. \& Helinski, D. R. (1992). A region of the broad-host-range plasmid RK2 causes stable in planta inheritance of plasmids in Rhizobium meliloti cells isolated from alfalfa root nodules. J Bacteriol 174, 7486-7489.

Xi, C., Dirix, G., Hofkens, J., De Schryver, F. C., Vanderleyden, J. \& Michiels, J. (2001). Use of dual marker transposons to identify new symbiosis genes in Rhizobium. Microb Ecol 41, 325-332.

Yang, F., Moss, L. G. \& Phillips, G. N. J. (1996). The molecular structure of green fluorescent protein. Nature Biotechnol 14, $1246-1251$. 